\title{
The Implication of Job Satisfaction That Influence Workers To Practice Organizational Citizenship Behavior (Ocb) In The Work Place
}

\author{
Mochamad Soelton \\ School of Economics and Management, Mercu Buana University, Indonesia \\ Nicko Alexander Visano \\ School of Economics and Management, Mercu Buana University, Indonesia \\ Noermijati Noermijati \\ School of Economics and Management, Brawijaya University, Indonesia \\ Yanto Ramli \\ School of Economics and Management, Mercu Buana University, Indonesia \\ Tanti Yanuar Rahmat Syah \\ School of Economics and Management, Esa Unggul University, Indonesia \\ Yosi Jandriana Sari \\ School of Economics and Management, Mercu Buana University, Indonesia
}

\begin{abstract}
This research aims to examine and analyze the political organization, organizational climate and organizational culture with organizational citizenship behavior (OCB) and job satisfaction as an intervening variable for employees of Distributor Company. The object of this research is 73 employees of Distributor Company. The approach used in this research is Component or Variance Based Structural Equation Model with analysis tool Smart-PLS. The results showed Political organizationa that has positive significant effect on job satisfaction. Organizational climate that has positive significant effect on job satisfaction to employees Distributor Company. Organizational culture that has positive significant effect on job satisfaction. Political organization does not affect organizational citizenship behavior (OCB). Organizational climate that has positive significant effect on organizational citizenship behavior (OCB). Organizationa culture that has positive significant effect on organizational citizenship behavior (OCB). Job satisfaction that has positive significant effect on organizational citizenship behavior (OCB).
\end{abstract}

Keywords: Political Organizational, Organizational Climate, Organizational Culture, Job Satisfaction, Organizational Citizenship Behavior (OCB). 
Soelton, M., Visano, N. A., Noermijati, N., Ramli. Y., Syah. T. Y. R., \& Sari, Y. J. (2020) The Implication Of Job Satisfaction That Influence Workers To Practice Organizational Citizenship Behavior (Ocb) In The Work Place. Archives of Business Research, 8(5). 33-48.

\section{INTRODUCTION}

Human Resources (HR) is an important element in a company because it can be a source of company competitive advantage or arguably the most important asset in an organization. Superior products or services at competitive prices and fast delivery times can be created if the company has high-quality human resources. The success or failure of a company will usually be marked by the company's ability to manage its human resources (Ukkas and Latif 2017). Distributor company is a company engaged in the sole distributor of Mitsubishi and electricity in Indonesia which has been established for 47 years. Various kinds of electrical appliances are sold here such as electrical components, electrical distribution equipment, installations, and other electronic component equipment. This research focuses on the employees of Distributor company located in Muara Karang, North Jakarta.

The phenomenon that occurs in this study where employees at Distributor company is experiencing dissatisfaction in their work, because things that can interfere with their routines such as dissatisfaction with superiors and organizations that according to some employees there are actions by individuals directed at self-elevation goals. And the employee explained that what was felt at work was quite difficult because they had to do extra behavior such as having to approach personally to the boss. Dissatisfaction felt by employees allegedly caused by employees still feel what they have received in the form of compensation is still far from what is expected Soelton and Atnani, (2018, Jumadi Et al, (2018), Hafid and Prasetio (2017), Wahyuni et al (2014)

This is a general attitude towards work that is based on an assessment of aspects that exist in the job. A person's attitude will describe something that is pleasant or unpleasant in the work environment and this will also relate to expectations in the future (Soelton, 2018), (Ramli and Soelton, 2018), and (Wahyuni el al., 2016). If employees show a positive attitude towards work, they show that they are satisfied with the job. Dissatisfaction felt by employees allegedly caused by employees still feel what they have received in the form of compensation is still far from what is expected according to Sekaran (Habib et al., 2014).

Employees still feel the existing reward distribution system is inadequate, especially in terms of the amount and allocation of benefits between employees. Hermawan (2016) states that if someone craves something, it means that the person has a hope and thus will be motivated to take action towards achieving that expectation. This feeling of injustice is feared to have an impact on employee commitment. If these expectations are fulfilled, satisfaction will be felt.

In addition to job satisfaction, another factor that triggers an increase or not is organizational citizenship behavior (OCB) where it is important to have organizational citizenship behavior (OCB) so that all employee tasks can be completed. Employees not only do their main tasks, but also want to do extra behavioral tasks such as willing to work together, being pleased in helping, advise fellow employees, participate actively, provide extra services and want to use work time effectively (Ramli and Soelton, 2018), (Lubis, 2015).

It can be said that employees who have the nature of loyalty will have a great impact on other employees (Soelton and Rakadishi, 2018). According to Ebrahimi et al,. (2013) organizational citizenship behavior describes a collection of voluntary behaviors that are not part of one's responsibilities, but they are carried out by them and lead to an effective increase in organizational 
responsibilities and roles. Based on an interview with Manager's, an employee of Distributor company have found problems that are indicated to arise due to the low organizational citizenship behavior (OCB), which is due to the number of employees who are late and neglect causes some employees to take the initiative to help the work of lazy coworkers and in the end the nature of OCB arises. Where employees want to handle the work of colleagues who do not enter.

According to Maamari and Messarra (2012), in today's organizational world characterized by expectation of higher work productivity, it is not surprising that organizations are in need of employees who go beyond their call of duty and give job performances that exceed expectations, i.e. engage in organizational citizenship behavior. This means that in today's world of organizations characterized by expectations of higher work productivity, it is not surprising that organizations need employees who go beyond the call of duty and provide performance that exceeds expectations, which is involved in organizational citizenship behavior. Study conducted by Badawy et al., (2016) employees engaged in citizenship behavior to help each other and tighten their social relationships. The low level of organizational citizenship behavior (OCB) of employees is indicated by several factors, namely lack of job satisfaction, other interests during working hours, dissatisfaction with superiors and organizations, lack of communication between employees and incompatibility with colleagues is also one of the causes of low organizational citizenship employee behavior (OCB). That causes conflicts between employees and will affect their daily lives in the office. But not all employees are indifferent to the surrounding environment, there are still employees who are willing to help other employees when difficulties. The results of the pre-survey showed an indication of organizational politics where the researchers also conducted interviews with several employees, they stated that it is true that many employees take personal approach to superiors for personal gain. And there are even employees who take actions that defame colleagues in order to get the attention of superiors, this is all a result of having someone motivated to take action towards achieving these expectations.

According to Ferris et al., In Hassan $\mathrm{H}$ et al., (2017) the perception of organizational politics will increase when individual behavior is not consistent with the rules set by the organization. This is also consistent with the opinion of Fairuzzabadi et al., (2016) who defines organizational politics as behavior that is strategically made to optimize individual interests, even if they conflict with the shared goals of the organization or the interests of other individuals. A study conducted by Kartono and Suwandari (2010) shows that organizational politics is something bad, unfair, irrational, and is an unhealthy behavior. Another definition shows organizational politics as the act of taking power using various Buchanan techniques in Atta and Khan (2016) engaging in influencing activities aimed at increasing the self-interest or those of the organization (Rosen, Harris, \& Kacmar, 2009). And the results of the pre-survey show that the obstacle found in employees related to Climate Organization is a sense of workplace discomfort. This is because the rate of hot air during the day and lack of air conditioning causes employees to work productivity decreases.

Organizational climate is important to be created because the organizational climate is closely related to individual perceptions, namely about what has been given by the organization and is used as a basis for determining the behavior of future members. And organizational climate affects job satisfaction. Where the organizational climate must run well in order to trigger better employee performance and can lead to a sense of satisfaction for the individual employees themselves (Nabilah, Tewal and Trang, 2017). Organizational climate influences the practices and policies of 
Soelton, M., Visano, N. A., Noermijati, N., Ramli. Y., Syah. T. Y. R., \& Sari, Y. J. (2020) The Implication Of Job Satisfaction That Influence Workers To Practice Organizational Citizenship Behavior (Ocb) In The Work Place. Archives of Business Research, 8(5). 33-48.

Human Resources (HR) that are accepted by members of the organization. Please note that each organization will have a different organizational climate. The diversity of jobs designed within the organization or the nature of existing individuals will illustrate these differences (Hermawan, 2016). According to Putra et al., (2018) stated organizational culture as a cognitive framework consisting of attitudes, values, norms of behavior and expectations that are shared by members of the organization. And according to a study conducted by Ghashghaeinia and Hafezi, (2015) In fact, the desired organizational culture can be a stimulus for efficiency and can increase employee productivity which is to create and strengthen organizational citizenship behavior. Because with a strong organizational culture will trigger employees to think, behave and behave in accordance with organizational values which include professionalism, trust in colleagues, and integration (Wahyuni et al., 2016).

Hanging out when work is loose has become commonplace for employees, but it will be a concern if employees continue to make irregularities during working hours, of course this will become a culture if not addressed, these deviations must be immediately followed up by leaders so employees others don't imitate wrong behavior. Organizational culture has a strong and profound impact on employee performance, which helps employees to be complacent with the organization and which causes to increase employee productivity. Organizational policies regarding culture must be clear to understand employees. Employee behavior towards their work and organization is influenced by organizational and cultural policies. Organizations must have a flexible culture (Habib et al., 2014). Based on previous research conducted by Gunawan and Santosa (2012) that organizational politics have an influence on how employees perceive their organizations. Observations that authors did at the company Distributor company pointed out that organizational politics happened there and ultimately prevented this employee from achieving satisfaction at work.

\section{Human Resource Challenges}

\section{LITERATURE REVIEW}

According to Hasibuan (2013), management is the science and art of regulating the process of utilizing human resources and other resources effectively and efficiently to achieve a certain goal. Meanwhile, according to Dessler (2013) human resource management is the process of acquiring, training, appraising and compensating employees, and attending to their labor relations, health and safety, and fairness concerns.

And According to Moekijat (2010) Human resource management can be defined as the process of achieving organizational goals through obtaining, maintaining, stopping, developing, and using / utilizing human resources in an organization as well as possible. Thus, Human Resource Management can be defined as a process consisting of planning, organizing, implementing, and controlling human resources in an organization to manage and ensure the effective and efficient use of human talent to achieve the stated goals.

\section{Job Satisfaction}

Job satisfaction is basically something that is individual. Each individual has a different level of satisfaction in accordance with the value system that applies to him. Employees who do not get job satisfaction will never achieve psychological satisfaction and eventually will arise negative attitudes or behavior and in turn can cause frustration (Ivancevich et al,. 2006). 
Sutrisno (2011) stated that job satisfaction is a pleasant or unpleasant emotional state for employees to view their work. Meanwhile, according to Suhendi \& Anggara (2010) job satisfaction is a (positive) attitude towards the workforce, which arises based on an assessment of the work situation. Job satisfaction shows a match between a person's expectations that arise and the rewards provided by work, so job satisfaction is also closely related to theories of justice, psychological agreements and motivation (Robbins \& Judge, 2009).

According to Luthans (2011) the factors used to measure job satisfaction are :

- Job itself - The extent to which individuals learn, take responsibility for the work received, elements of satisfaction in work.

- Salary / Wages - The amount of financial remuneration received, to the extent seen as equivalent to the others, the suitability of wages received.

- Promotion Opportunities - Opportunities are accepted for organizational progress, promotion, promotion as employee motivation to progress.

- Supervision - Ability possessed by supervisors to assist employees, Ability possessed by supervisors to support employees, Supervision of work.

- Co-workers -Co-worker skills, Supporting individuals socially, harmonious relationships.

\section{Organizational Citizenship Behavior (OCB)}

Organizational Citizenship Behavior (OCB) is behavior that arises at the discretion of an employee which is done voluntarily and without coercion. This behavior goes beyond the formal demands of the job or formal job description Smith in Andriani (2012) and the role of OCB (Organizational Citizenship Behavior) is one of the factors that most determine the company's success (Jumadi et al., 2018).

And according to Budihardjo (2014) argues that organizational citizenship behavior (OCB) has characteristics of voluntary behavior (extra-role behavior) that are not included in job descriptions, spontaneous behavior or no one's target or order, behavior that is helpful, and behavior that is not easy seen and assessed through performance evaluation. Organizational Citizenship Behavior (OCB) is a positive employee behavior towards colleagues in order to achieve the objectives of the organization Djati (2009). This behavior illustrates the added value of employees which is one form of pro-social behavior that is positive, constructive and meaningful social behavior (Soelton and Rakadishi, 2018).

According to Titisari (2014) Dimensions of Organizational Citizenship Behavior (OCB), that is:

- Altruism - Replacing co-workers who don't go in or resting, helping others overload, helping others outside the department when they have problems.

- Conscientiousness - Arrive early, so be ready to work when the schedule starts, Be on time every day, Don't spend time talking outside of work.

- Sportmanship - Not finding fault in the organization, Not complaining about everything, Not exaggerating problems beyond proportion.

- Courtesy - Involvement in organizational functions, Give attention to functions that help the image, Respect the privacy and rights of co-workers.

- Civic Virtue - Follow the changes, Participate in various activities organized by the organization, Provide innovative advice to improve the quality of the organization. 
Soelton, M., Visano, N. A., Noermijati, N., Ramli. Y., Syah. T. Y. R., \& Sari, Y. J. (2020) The Implication Of Job Satisfaction That Influence Workers To Practice Organizational Citizenship Behavior (Ocb) In The Work Place. Archives of Business Research, 8(5). 33-48.

\section{Political Organization}

Political behavior is an informal force owned by employees which can influence distributor profit and loss in the organization. According to Sunyoto \& Burhanudin (2011) organizational politics can be defined as an increase in self-interest / self-interest which is done intentionally. Where organizational politics as an act of intentional influence with the aim to increase or protect themselves desires of individuals or groups (Ivancevich et al,. 2006).

Meanwhile, according to Robbins and Judge (2011) political behavior is defined as activities that are not considered as part of a person's formal role in organizations. And according to Ahmad et al.. (2017) Organizational politics means every action taken within the organization to develop, obtain and use power to achieve personal goals.

Chen \& Fang (2008) stated organizational politics has three dimensions, that is:

- Organizational practices and policies - Done by developing themselves in the organization by bringing down other people, determining certain positions or positions determined by political interests, more saying what you want to hear is not the truth.

- Colleagues behavior - Done by offering help because there is a hidden purpose, Showing goodness only to show a positive image, saving / distorting information requested by other colleagues.

- Go along to get ahead - By way of freedom of speech even though it is contrary to standard rules, a good idea is allowed even if it is contrary to the majority's idea. Organizational politics is used as a tool to achieve something that is desired.

\section{Organization Climate}

There are several organizational climate definitions put forward by experts, one of which is by Wirawan (2007) he defines that organizational climate is the perception of members of the organization (individually and in groups) and those who are constantly in contact with organizations (eg suppliers, consumers, consultants, and contractors) about what is or happens in the internal environment of the organization on a regular basis, which influences the attitudes and behavior of the organization and the performance of members of the organization which then determines the organization's performance.

According to Wirawan (2007) outlining a number of examples of organizational climate dimensions, that is:

- State of the physical environment - Workplace, Furniture, Production Equipment and so on.

- Social environment - Relationship between superiors and subordinates, Relationships between coworkers, Cooperation in carrying out tasks

- Implementation of management systems - Organizational structure, Work standards, Work procedures

- Physical and psychological condition of organization members - Agility, Health, Togetherness

- Organizational culture - Implementation of norms, Implementation of code of ethics, Organizational history 


\section{Organizational Culture}

Organizational culture according to Wirawan (2007) is the norms, values, assumptions, beliefs, philosophies, organizational habits, etc., the founders, leaders and members of the organization are socialized and taught to new members and applied in organizational activities so that it affects thought patterns, attitudes and organizational member behavior in serving consumers, and achieving organizational goals. And organizational culture is one of the assets or physical resources (observable) and non-physical (unobservable) which typically contains assumptions, values, norms, commitment and trust, useful to encourage and improve the efficiency and effectiveness of public and private organizations Suhendi \& Anggara (2010). Organizational culture according to Didit (2013) is a set of core values, beliefs and attitudes that are enforced among members of the organization. Where employees must have good ethics as employees.

According to Robbins and Judge (2017) there are seven primary characteristics that collectively capture the nature of organizational culture, that is:

- Innovation and risk taking - Having an innovative attitude, Daring to take risks must exist within the organization, Encouraged to be innovative.

- Attention to details - In the organization must pay attention to all provisions and analysis, Pay more attention to things around, Carry out the task carefully and precisely

- Results orientation - Focus on the final result, Develop the potential for the final result, Effectiveness of the final result.

- People orientation - The extent to which management decisions take into account the effect of results on people in the organization, Carry out tasks according to procedures, Take advantage of opportunities that exist.

- Team orientation - The ability of teamwork, does not work individually, helps or helps between employees.

- Aggressiveness - Individuals in the organization have a competitive attitude, work to be aggressive towards work, consistent with work.

- Stability - Working in accordance with the current state of the organization, Maintaining the status quo to develop and progress, the environmental conditions of the organization. 


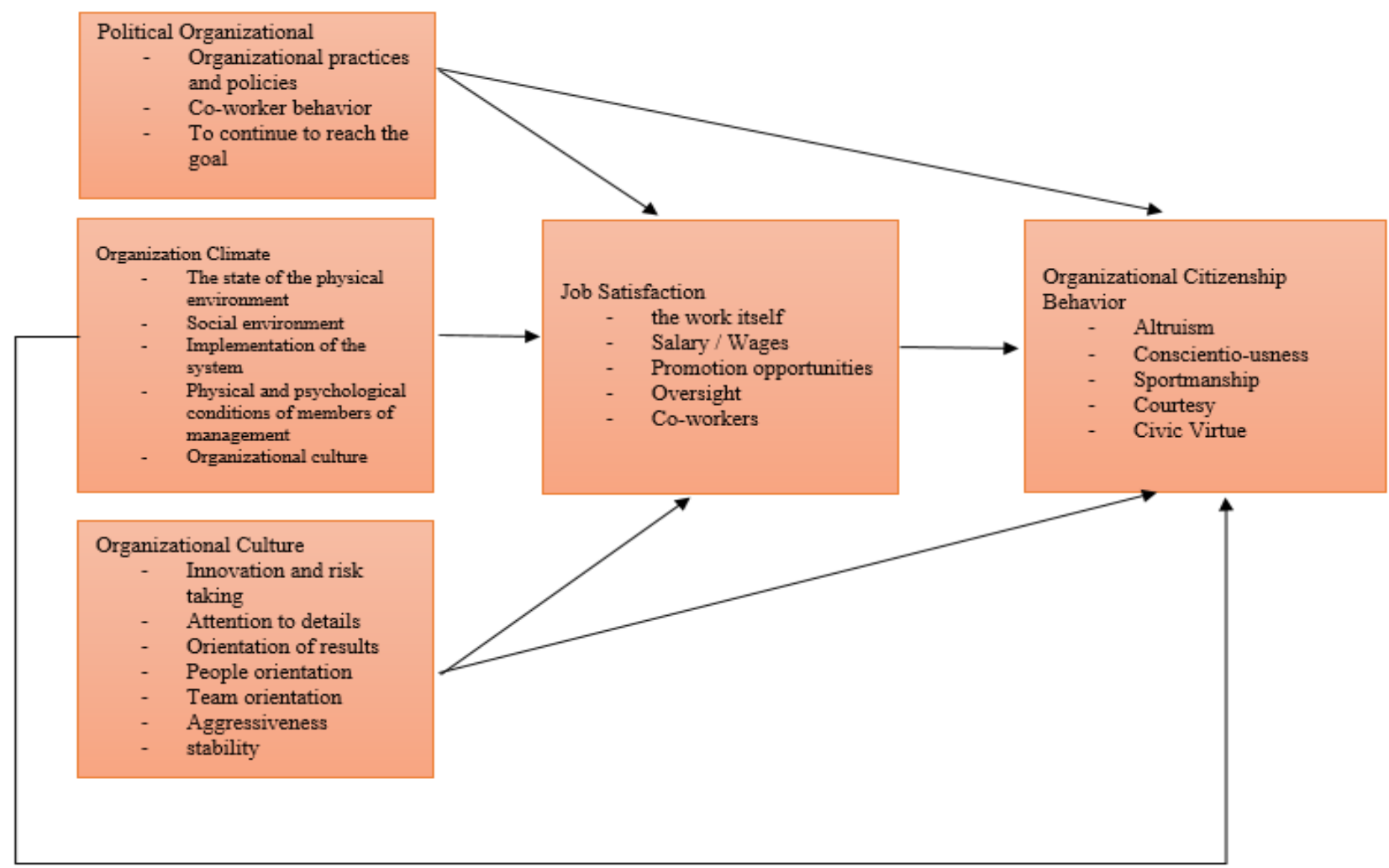

Figure 1: Research Paradigm

\section{METHODOLOGY}

The design of this research is using human resource management approach that include the operational variables, data collection method and information collection, defining the population, calculating the sample size and sampling techniques. This research begins with the preliminary research and follow by formulating the construct variables.

The formulation and purpose of this study is to describe and reveal the interrelationship between the research variables explained above. This research is using descriptive and verification method with the type of causal research on the relationship and influence between the exogenous and endogenous variables. The process of observation in this research is using time horizon with cross section/one shot, the collective data is obtained from the research done in 2019, the unit of analysis are the employee warehouse section in Jakarta, Indonesia. The design of analysis is using Partial Least Square (PLS) as the alternative method from Structural Equation Modeling (SEM).

The validity testing was done by using the sample of 73 respondents randomly on the employee warehouse section company. The attempt of this validity testing is to find out the eligible of the selected items including the overall data collection process. The result of the validity test are as follows. 
Table 1: Validity Test Results

\begin{tabular}{|c|c|c|c|}
\hline Variable & Indikator & Outer Loading & Description \\
\hline \multirow{8}{*}{ Organizational Climate } & OC3 & 0.695 & Valid \\
\hline & OC4 & 0.909 & Valid \\
\hline & OC5 & 0.615 & Valid \\
\hline & OC6 & 0.759 & Valid \\
\hline & OC7 & 0.776 & Valid \\
\hline & OC8 & 0.806 & Valid \\
\hline & OC9 & 0.573 & Valid \\
\hline & OC10 & 0.774 & Valid \\
\hline \multirow{16}{*}{ Organizational Culture } & 02 & 0.527 & Valid \\
\hline & 05 & 0.531 & Valid \\
\hline & 06 & 0.631 & Valid \\
\hline & 07 & 0.783 & Valid \\
\hline & 09 & 0.752 & Valid \\
\hline & 010 & 0.704 & Valid \\
\hline & 011 & 0.655 & Valid \\
\hline & 012 & 0.553 & Valid \\
\hline & 014 & 0.699 & Valid \\
\hline & 015 & 0.630 & Valid \\
\hline & 016 & 0.534 & Valid \\
\hline & 017 & 0.807 & Valid \\
\hline & 018 & 0.634 & Valid \\
\hline & 019 & 0.686 & Valid \\
\hline & 020 & 0.729 & Valid \\
\hline & 021 & 0.812 & Valid \\
\hline \multirow{10}{*}{ Job Satisfaction } & JS1 & 0.610 & Valid \\
\hline & JS2 & 0.783 & Valid \\
\hline & JS3 & 0.603 & Valid \\
\hline & JS4 & 0.660 & Valid \\
\hline & JS5 & 0.588 & Valid \\
\hline & JS6 & 0.529 & Valid \\
\hline & JS10 & 0.744 & Valid \\
\hline & JS11 & 0.712 & Valid \\
\hline & JS12 & 0.790 & Valid \\
\hline & JS13 & 0.727 & Valid \\
\hline \multirow{11}{*}{$\begin{array}{c}\text { Organizational Citizenship } \\
\text { Behaviour }\end{array}$} & OCB1 & 0.620 & Valid \\
\hline & OCB2 & 0.867 & Valid \\
\hline & OCB3 & 0.689 & Valid \\
\hline & OCB5 & 0.688 & Valid \\
\hline & OCB7 & 0.779 & Valid \\
\hline & OCB8 & 0.703 & Valid \\
\hline & OCB9 & 0.707 & Valid \\
\hline & OCB11 & 0.531 & Valid \\
\hline & OCB12 & 0.639 & Valid \\
\hline & OCB14 & 0.779 & Valid \\
\hline & OCB15 & 0.616 & Valid \\
\hline
\end{tabular}

Source: From data processing (2019) 
Soelton, M., Visano, N. A., Noermijati, N., Ramli. Y., Syah. T. Y. R., \& Sari, Y. J. (2020) The Implication Of Job Satisfaction That Influence Workers To Practice Organizational Citizenship Behavior (Ocb) In The Work Place. Archives of Business Research, 8(5). 33-48.

Based on table 1 above, the calculation of the item score correlation with the total score show that the validity coefficient is greater than 0.300 , so all the items used to measure the said variables are considered as valid. The reliability test of this research data is using Cronbach's Alpha coefficient method. The Cronbach's Alpha coefficient is the reliability coefficient that are most commonly used because the coefficient will indicate the variance of items with either correct or incorrect format such as Likert scale format.

The criteria of determining a valid item and having a reliable value that can be accepted are based on the table described below

Tabel 2: Standard Composite Reliability \& Cronbach's Alpha

\begin{tabular}{|c|c|c|c|}
\hline Variable & $\begin{array}{c}\text { Cronbach } \\
\text { Alpha's }\end{array}$ & $\begin{array}{c}\text { Composite } \\
\text { Reliability }\end{array}$ & Description \\
\hline Political Organization & 0.799 & 0.786 & Reliabel \\
\hline Organizational Climate & 0.884 & 0.908 & Reliabel \\
\hline Organizational Culture & 0.917 & 0.929 & Reliabel \\
\hline Job Satisfaction & 0.871 & 0.894 & Reliabel \\
\hline Organizational Citizenship Behaviour & 0.892 & 0.911 & Reliabel \\
\hline
\end{tabular}

Source: From Data Processing (2019)

The result of the above calculation of the score items with the total based on the table above has a reliability coefficient Cronbach Alpha's value which is greater 0,7 which means that all instruments can be classified as reliable.

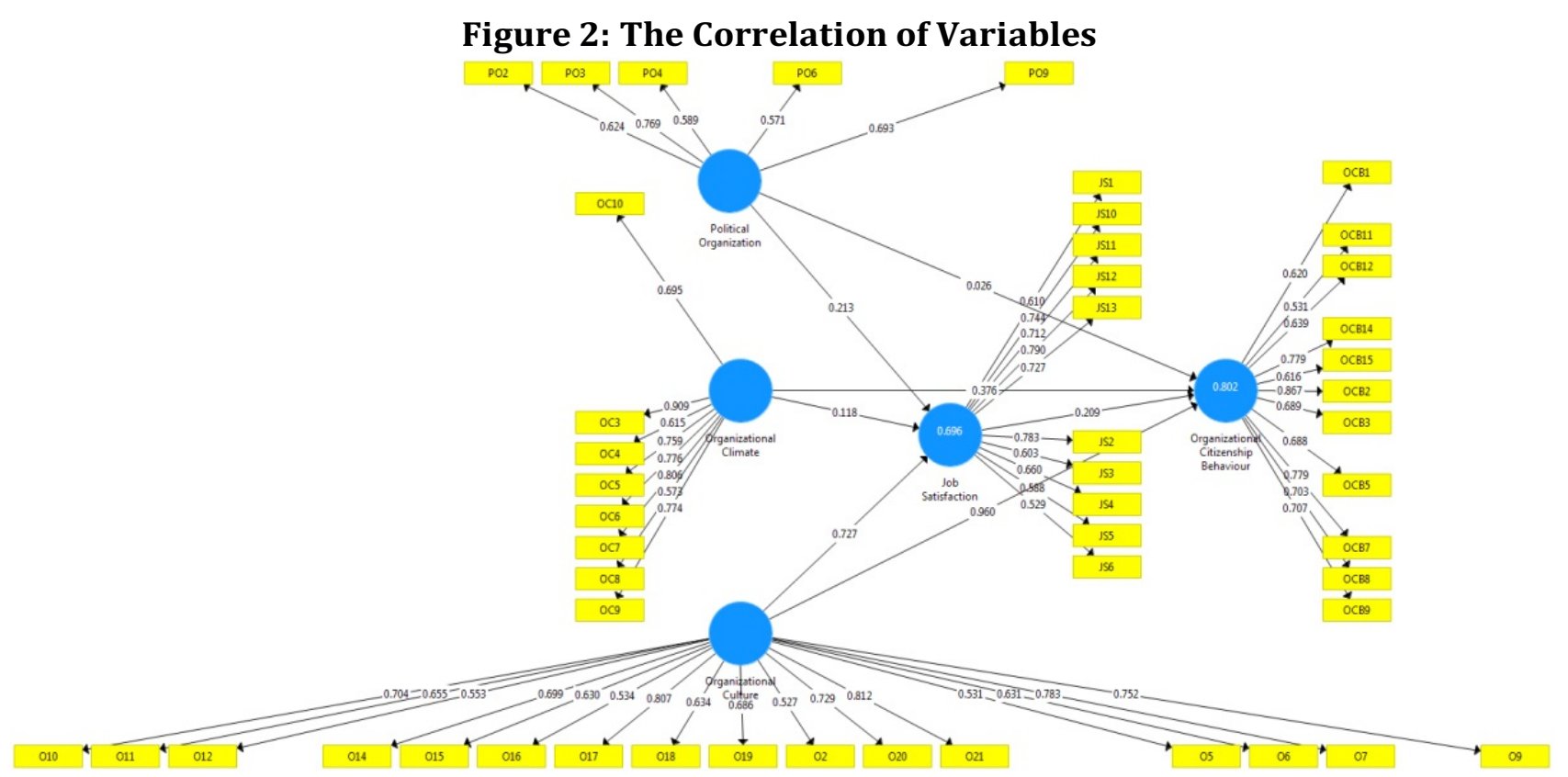

Source: From Data Processing (2019)

\section{RESULT AND DISCUSSION}

The measurement model of analysis above shows the link between manifest variables (indicators) and each of the latent variables. The analysis of the measurement model is to test the validity and reliability of each of the dimensions and the indicators utilized to measure the variables 
constructed earlier. The analysis of the measurement model describe that the value of discriminant validity is by looking at the value of square root of Average Variance Extracted (AVE) with the suggestion value above 0,5 , loading factor $(>0.5)$, and constructed Composite Validity and Reliability (Cronbach's Alpha >0.70). Therefore, the conclusion of the dimensions and indicators which are classified as reliable earlier are showed below:

Table 4: Goodness of Fit Model (GoF)

\begin{tabular}{|c|c|}
\hline Variabel Endogen & R-square \\
\hline Job Satisfaction & 0.696 \\
\hline Organizational Citizenship Behavior & 0.802 \\
\hline
\end{tabular}

Source: From data processing (2019)

Predictive relevance value is obtained by the formula:

$\mathrm{Q}^{2}=1-(1-\mathrm{R} 1)\left(1-\mathrm{R}_{\mathrm{p}}\right)$

$\mathrm{Q}^{2}=1-(1-0.696)(1-0.802)$

$\mathrm{Q}^{2}=1-(0.304)(0.198)$

$\mathrm{Q}^{2}=0.9398$

From the above Goodness of Fit table it pointed out that the value of R2 shows that the criteria are strong, with a large $Q$ value, it can be concluded that the proposed model is supported by empirical research which is quite suitable. Likewise, the AVE values are $>0.5$, indicating that all variables in the model are estimated to meet the discriminant validity criteria. The value of Composite Reliabitily and Cronbach's Alpha for each variable is $>0.70$ (above 0.70 ) meaning that all variables studied are classified as reliable.

Table 5: Hypothesis Testing Results

\begin{tabular}{|l|c|c|c|c|c|}
\hline & $\begin{array}{c}\text { Original } \\
\text { Sample }\end{array}$ & $\begin{array}{c}\text { Standard } \\
\text { Deviation }\end{array}$ & T-Statistics & P Values & Keterangan \\
\hline $\begin{array}{l}\text { Political Organizational } \rightarrow \\
\text { Job Satisfaction }\end{array}$ & 0.213 & 0.163 & 2.185 & 0.045 & Positive - Significant \\
\hline $\begin{array}{l}\text { Organizational Climate } \\
\rightarrow \text { Job Satisfaction }\end{array}$ & 0.118 & 0.119 & 2.987 & 0.024 & Positive - Significant \\
\hline $\begin{array}{l}\text { Organizational Culture } \\
\rightarrow \text { Job Satisfaction }\end{array}$ & 0.727 & 0.119 & 6.108 & 0.000 & Positive - Significant \\
\hline $\begin{array}{l}\text { Political Organizational } \rightarrow \\
\text { OCB }\end{array}$ & 0.026 & 0.107 & 1.008 & 0.853 & $\begin{array}{c}\text { Not } \\
\text { Organizational Climate } \rightarrow \\
\text { OCB }\end{array}$ \\
\hline $\begin{array}{l}\text { Organizational Culture } \rightarrow \\
\text { OCB }\end{array}$ & 0.376 & 0.114 & 3.285 & 0.001 & Positive - Significant \\
\hline \begin{tabular}{l} 
Job Satisfaction $\rightarrow$ OCB \\
\hline
\end{tabular} & 0.209 & 0.103 & 2.030 & 0.043 & Positive - Significant \\
\hline
\end{tabular}

Source: From data processing (2019) 
Soelton, M., Visano, N. A., Noermijati, N., Ramli. Y., Syah. T. Y. R., \& Sari, Y. J. (2020) The Implication Of Job Satisfaction That Influence Workers To Practice Organizational Citizenship Behavior (Ocb) In The Work Place. Archives of Business Research, 8(5). 33-48.

From the results of hypothesis testing, it was political organizational positive and significant effect on job satisfaction and organizational climate has a positive and significant effect on job satisfaction.While organizational culture has a positive and significant effect on job satisfaction and political organizational does not significantly influence organizational citizenship behavior (OCB). organizational climate has a positive and significant effect on organizational citizenship behavior (OCB). organizational culture has a positive and significant effect on organizational citizenship behavior (OCB). job satisfaction has a positive and significant effect on organizational citizenship behavior (OCB).

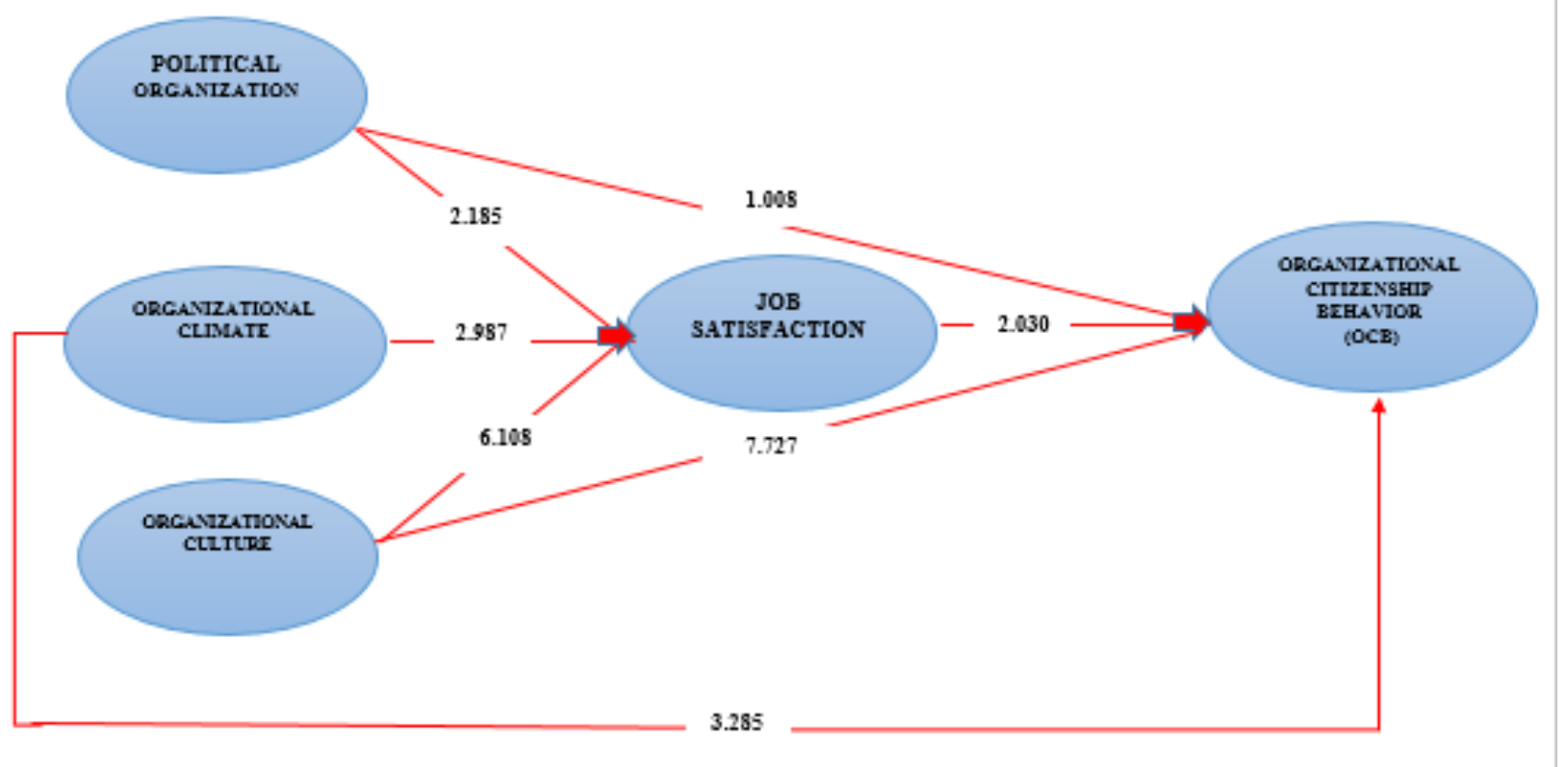

Source: Form data processing (2019)

Figure 3: The Testing Result

Based on the testing result above, the research variables indicated that organizational culture has the most significant influence on job satisfaction as the intervening variable, which is 6.108 compare to the variable of political organization which is 2.185 and climate organization which is 2.987. The direct effect of organizational culture also contributed influence towards organizational citizenship behavior with the figure of 7.727 compare to career development with the figure of 3.285 and political organization with the figure of 1.008. Even job satisfaction has a highest direct effect of against organizational citizenship behavior with the figure of 2.030 .

\section{Conclusion}

\section{CONCLUSION AND RECOMMENDATION}

The result of the hypothesis testing concluded that a proper leadership style can make a significant difference in the working environment and obtain the organizational commitment of the workforce and prevent them from taking the action of leaving the company to seek better offer of job outside the company.

The objectives of this research are to find out the basic issues encounter by the company of IT provider and products concerning the turnover intention of the employees in Jakarta, Indonesia. 
This research has constructed that seven research variables in order to find out the main cause of the problem. The result of the hypothesis testing conclude several findings as follows:

1. Political organizational significant positive effect on job satisfaction on employees of Distributor company. This means that if organizational politics are high in the company, it will increase employee job satisfaction.

2. Organizational climate has a significant positive effect on job satisfaction among employees of Distributor company. This means that if the organizational climate is good, employee satisfaction will increase.

3. Organizational culture has a significant positive effect on job satisfaction among employees of Distributor company. This means that the better the organizational culture in the company, the employee job satisfaction will increase.

4. Political organization has no effect on organizational citizenship behavior (OCB) on the employees of Distributor company. This means that the organizational citizenship behavior of employees is not determined by the presence or absence of politics in the organization.

5. Organizational climate has a significant positive effect on organizational citizenship behavior (OCB) on the employees of Distributor company. This means that if the organizational climate of a company is good, it will increase the organizational citizenship behavior (OCB) attitude of employees.

6. Organizational culture has a significant positive effect on organizational citizenship behavior (OCB) on the employees of Distributor company. This means that if the organizational culture is good, it will increase the attitude of organizational citizenship behavior (OCB) employees.

7. Job satisfaction has a significant positive effect on organizational citizenship behavior (OCB) for Distributor company employees. This means that if employee job satisfaction is high, it will further enhance the organizational citizenship behavior (OCB) attitude of employees.

The result of this research is to bring into attention that this phenomenon that may also occured in the rest of the country. It would be worthwhile to study further the political organization and job satisfaction at the company.

\section{Recommendation}

Based on the conclusion above, the results of this study has pointed out that the organization today must pay more attention and understand the millennial workforce because they are somehow very different from the previous generation, and in order to achieve long-term success, the organization must meet the challenge of managing a diverse characters of the millennial workforce.

It is crucial to understand how to motivate this millennials and develop a clear HR system for reward and punishment to discipline the employees and also giving motivation to develop their way of thinking to perform their tasks. There is also a need of proper training skills for the employees to prevent them from making mistakes and perform a better improvement of performance. The managers and leaders must attend the intensive leadership training in order to build the leadership style of the company's managers and leaders. The organizations may take this research as a guidance to proceed with further study to understand the millennial workforce and turnover intention and how to motivate them to provide better improvement in the organizations. 
Soelton, M., Visano, N. A., Noermijati, N., Ramli. Y., Syah. T. Y. R., \& Sari, Y. J. (2020) The Implication Of Job Satisfaction That Influence Workers To Practice Organizational Citizenship Behavior (Ocb) In The Work Place. Archives of Business Research, 8(5). 33-48.

\section{References}

1. Ahmad, J., Muhammad, A.W.H, Rahman, U.H, Imran, M.R, \& Ain, U.N. (2017). Effect Of Diversified Model Of Organizational Politics On Diversified Emotional Intelligence. Journal of Basic \& Applied Sciences, 2017, 13, 375385.

2. Andriani, Gita. (2012). Organizational Citizenship Behavior dan Kepuasan kerja pada Karyawan. Jurnal Penelitian Psikologi, Vol. 03, No. 01, pp341-354.

3. Atta, M. \& Khan, M. J. (2016). Perceived Organizational Politics, Organizational Citizenship Behavior And Job Attitudes Among University Teachers. Journal of Behavioural Sciences, Vol. 26, No. 2, 2016.

4. Badawy, T. A. E., Kamel M. M., dan Magdy. M. M. (2016). Exploring the Relationship between Organizational Culture, Job Satisfaction and Organizational Citizenship Behavior. International Journal of Human Resource Studies ISSN 2162-3058 2016, Vol. 6, No. 4

5. Budihardjo, M. (2014). Panduan Praktis Menyusun SOP. Jakarta: Raih Asa Sukses.

6. Chen, Yei-Yi and Fang W. 2008. The Moderating Effect of Impression Management on the Organizational PoliticsPerformance Relationship. Journal Of Business Ethics, 79, 263-277 congruence with culture dimensions during organizational transformation.

7. Dessler, Garry. 2013. Human Resource Management - Thirteenth Edition. New Jersey: Prentice Hall.

8. Didit Dermawan. (2013). Prinsip- Prinsip Perilaku Organisasi. Surabaya: Pena Semesta.

9. Djati, S. P. (2009). Variabel Anteseden Organizational Citizenship Behavior (OCB) dan Pengaruhnya Terhadap Service Quality Pada Perguruan Tinggi Swasta di Surabaya. Jurnal Aplikasi Manajemen (JAM), Vol. 7, No. 3, Agustus 2009.

10. Ebrahimi, A., Mirjafari, A., \& Mostafavi, F. (2013). The Relationship between organizational climate and organizational citizenship behaviour. J. Basic. Appl. Sci. Res., 3(2)1045-1050, 2013

11. Ghashghaeinia. A. R., dan HAFEZI. S. (2015). Relationship between organizational culture and organizational citizenship behavior among personnel of Islamic Azad University of

12. Fars. J. Appl. Environ. Biol. Sci., 5(11S)131-138, 2015

13. Gunawan dan Santosa, T.E.C. (2012). Politik Organisasi dan Dampaknya Terhadap Komitmen Organisasi, Kepuasan Kerja, Kinerja dan Organizational Citizenship Behavior (OCB). Jurnal Manajemen, Vol.12, No.1, November 2012.

14. Hassan H., Vina T.M.H., Ithnin N.S. (2017). Perceived Organizational Politics And Job Satisfaction: The Role Of Personality As Moderator. LogForum 13 (4), 479-493,http://dx.doi.org/10.17270/J.LOG.2017.4.8 Received: 05.05.2017, Accepted: 28.07.2017, on-line: 29.09.2017.

15. Habib, S., Aslam, S., Hussain, A., Yasmeen, S,. \& Ibrahim, M. (2014). The Impact of Organizational Culture on Job Satisfaction,Employess Commitment and Turn over Intention. Advances in Economics and Business 2(6): 215-222, 2014.

16. Hasibuan, Malayu S.P. (2013). Manajemen Sumber Daya Manusia Cetaka ke Tujuh Belas, Jakarta: PT Bumi Aksara.

17. Hermawan, G. (2016). Hubungan Iklim Organisasi Dengan Kepuasankerja Karyawan PT. Jembayan Muarabara Desa Separi Tenggarong Seberang. Mahasiswa Program Studi Psikologi, Fakultas Ilmu Sosial dan Ilmu Politik, Universitas Mulawarman. Email : galih.hermawan@gmail.com PSIKOBORNEO, 2016, 4 (2) : 374 - 373 ISSN 24772674, ejournal.psikologi.fisip-unmul.ac.id.

18. Fairuzzabadi, Murkhana Dan Ayu, M.P. (2016). Pengaruh Politik Organisasional Pada Kepuasan Kerja: Kepercayaan dan Dukungan Sosial Sebagai Pemoderasi. Jurnal Manajemen dan Inovasi Vol.7, No. 1, Februari 2016 : 1-23.

19. Ivancevich, J.M, Konopaske, R, \& Matteson, M.T. (2006) Organizational Behavior And Management, Seventh Edition. Edisi 7 Jilid 1. 
Archives of Business Research (ABR)

Vol.8, Issue 5, May-2020

20. Ivancevich, J.M, Konopaske, R, \& Matteson, M.T. (2006) Organizational Behavior And Management, Seventh Edition. Edisi 7 Jilid 1.

21. Jumadi., Soelton, Mochamad., Nugrahati, Tati. (2018). Bagaimanakah Beban Kerja dan Stress Kerja Mempengaruhi Organizational Citizenship Behaviour (OCB) dan Kinerja Karyawan PT. Multitek Indopanca Jakarta. Forum Manajemen Indonesia 10-Palembang, 501

22. Kartono dan Suwandari. (2010). Pengaruh Kepribadian dan Politik Organisasi Terhadap Kesuksesan Karier Serta Dampaknya Pada Kinerja Pegawai. Jurnal Ekonomi Universitas Jenderal Achmad Yani Vol.II, No 3 Hal. 1-19.

23. Lubis, M. Saleh. (2015). Pengaruh Iklim Organisasi dan Komitmen Organisasi terhadap Pembentukan Organizational Citizenship Behavior (OCB) Karyawan dalam rangka Peningkatan Kinerja. E-Jurnal Apresiasi Ekonomi 3(2): 75-84.

24. Luthans, F. (2011). Organizational Behaviour, Edition twelfth, McGraw-Hill/Irwin, New York.

25. Maamari, E.B., dan Messarra, C.L. (2012). An Empirical Study Of The Relationship Between Organizational Climate And Organizational Citizenship Behavior. EUROPEAN JOURNAL OF MANAGEMENT, Volume 12, Number 3, 2012165

26. Moekijat. (2010). Manajemen Sumber Daya Manusia. CV Mandar Maju, Bandung Hal. 4-5.

27. M Soelton, P Amaelia, H Prasetyo. 2020. Dealing with Job Insecurity, Work Stress, and Family Conflict of Employees.

28. 4th International Conference on Management, Economics and Business (ICMEB 2019). 2020/2 (167-174). atlantispress.com

29. M Soelton, D Amalia, N Noermijati, B Wahyudiono. 2020. Self-Esteem: The Levels of Religiosity in Job Insecurity and Stress in Government Company. 4th International Conference on Management, Economics and Business (ICMEB 2019). 2020/2 (302-310). atlantis-press.com

30. F Rohman, YB Abadi, M Soelton, N Prasetyo, ET Saratian. 2020. The Effect of Environmentally Friendly Paper Toward Purchasing Intention. 4th International Conference on Management, Economics and Business (ICMEB 2019). 2020/2 (120-126). atlantis-press.com

31. M Soelton, D Hardianti, S Kuncoro, J Jumadi. 2020. Factors Affecting Burnout in Manufacturing Industries. 4th International Conference on Management, Economics and Business (ICMEB 2019). 2020/2 (46-52). atlantispress.com

32. M Mugiono, BH Purwoko, M Soelton, R Yuvitasari. 2020. Recognizing How the Job Involvement, Burnout, and Self-Efficacy Work Influences the Work Stress at International Hospitals. 4th International Conference on Management, Economics and Business (ICMEB 2019). 2020/2 (264-270). atlantis-press.com

33. M Soelton, PA Lestari, H Arief, RL Putra. 2020. The Effect of Role Conflict and Burnout Toward Turnover Intention at Software Industries, Work Stress as Moderating Variables. 4th International Conference on Management, Economics and Business (ICMEB 2019). 2020/2 (185-190). atlantis-press.com

34. DF Suzabar, M Soelton, M Umar, J Triwulan. 2020. Recognizing How the Time Demands of Work Influences the Turnover Intention in Banking Industry. 4th International Conference on Management, Economics and Business (ICMEB 2019). 2020/2 (40-45). atlantis-press.com

35. A Nanda, M Soelton, S Luiza, ETP Saratian. 2020. The Effect of Psychological Work Environment and Work Loads on Turnover Interest, Work Stress as an Intervening Variable. 4th International Conference on Management, Economics and Business (ICMEB 2019). 2020/2 (225-231). atlantis-press.com

36. Nabilah, F.P., Tewal, B., \& Trang, I.,(2017). Pengaruh Pelatihan, Pendidikan dan Iklim Organisasi Terhadap Kepuasankerja Karyawan Pada PT. Pln (Persero) Sektor Pembangkitan Minahasa. Jurnal EMBA Vol.5 No.2 Juni 2017, Hal. $1882-1890$.

37. M Nurhayati, A Thoyib, DW Irawanto, 2019. Impersonal Trust and Perceived Organizational Politics on Organizational Commitment. European Research Studies Journal 21 (3), 391-403 | vol: | issue : | 2018 
Soelton, M., Visano, N. A., Noermijati, N., Ramli. Y., Syah. T. Y. R., \& Sari, Y. J. (2020) The Implication Of Job Satisfaction That Influence Workers To Practice Organizational Citizenship Behavior (Ocb) In The Work Place. Archives of Business Research, 8(5). 33-48.

38. M Nurhayatia, A Thoyib, N Noermijati, 2017. The Role of Political Skills for Organizational Commitment . International Journal of Economic Perspectives 11 (4), 493-498 | vol: | issue : | 2017

39. Putra, D.S., Susilo, H dan Aini, E.K. (2018). Pengaruh Budaya Organisasi Terhadap Organizational Citizenship Behavior (OCB) Dengan Kepuasan Kerja Sebagai Variabel Intervening. (Studi Pada Karyawan Kusuma Agrowisata Divisi Hotel Kota Batu). Jurnal Administrasi Bisnis (JAB)/Vol. 62 No. 2

40. Rosen, C. C., Harris, K. J., \& Kacmar, K. M. (2009). The emotional implications of organizational politics: A process model. Human Relations, 62(1), 27-57.

41. Robbins \& Judge (2017). Perilaku Organisasi, ( 1 st \& 2 nd Ed), Jakarta Penerbit Salemba Empat.

42. Robbins SP, dan Judge. (2009). Perilaku Organisasi Buku 3, Jakarta : Salemba Empat

43. Robbins, S. P., \& Judge, T. A. (2011). Perilaku organisi (terj). Jakarta: Salemba Empat

44. Soelton.Mochamad, Rakadishi, Jaya. (2018). How to Implementation of Organizational Citizenship Behaviour with Performance on Accident Insurance Service. Europian Journal of Business and Management Vol.10, No15.ISTE European Journal of Business and Management.

45. Soelton, M., Umar, M. (2018). Recognizing How The Time Demands of Work Influences the Turn Over Intention in Banking Industry. European Journal of Business and Management (EJBM), 12 (19)

46. Soelton, M. (2018). How Culture, Training Standard and Discipline on the Employee Performance Affect Hotel Management. European Research Studies Journal, 21(4), 378-385.

47. Soelton, M., \& Nugrahati, T. (2018). How Complaining Behaviors Effect on Coping Stress and Anxiety. International Journal of Saudi Journal of Business and Management Studies (SJBMS), 3(6), 623-628.

48. Soelton, M., \& Oktapriatna, N. (2018). How Complaining Behaviors Effect on Performance in Government Industries?. International Journal of Saudi Journal of Business and Management Studies (SJBMS), 3(6), 623-628.

49. Soelton, M., \& Rakasidhi, J. (2018). How to Implementation Organization Citizenship Behaviors with performance on Accident insurance service. European Journal of Business and Management (EJBM), 10(15), 10-16.

50. Soelton, M., Pebriani, P., Umar, M., Triwulan, J., \& Wilantara, J. How transformational leadership, communication, and workload on the employee performance affect shoes industries. South East Asia Journal of Contemporary Business, Economics and Law, Vol. 17, Issue 5(December) ISSN 2289-1560

51. Soelton, M., Nugrahati, T., Setiawan, M., Rohman, F., \& Pratama, A. (2019). Gender: Stress Levels On Performance In Modern Industry. Archives of Business Research, 7(2).

52. Suhendi, H \& Anggara, S (2010). Perilaku Organisasi. Bandung: CV Pustaka Setia.

53. Sunyoto, D. \& Burhanudin. (2011). Perilaku Organisasional, edisi pertama, CAPS, Yogyakarta.

54. Sutrisno, Edy. (2016). Manajemen Sumber Daya Manusia. Jakarta: Prenadamedia Group.

55. Ukkas, I. \& Latif, D. (2017) Pengaruh Iklim Organisasi Dan Komitmen Organisasi Terhadap Organizational Citizenship Behavior (OCB). Jurnal Equilibrium Vol. 06 No. 01 Februari ISSN 2089-2152Sekolah Tinggi Ilmu Ekonomi Muhammadiyah Palopo E_Mail: imranukkas@stiem.ac.id

56. Titisari, Purnamie. (2014). Peranan Organizational Citizenship Behaviour (OCB) Dalam Meningkatkan Kinerja Karyawan, Mitra Wacana Media, Jakarta

57. Wahyuni, Taufik dan Ratnawati. (2016). Pengaruh Budaya Organisasi, Locus Of Control, Stres Kerja Terhadap Kinerja Aparat Pemerintah Daerah Dan Kepuasan Kerja Sebagai Variabel Intervening (Studi Empiris Pada Pemerintah Kabupaten Bengkalis) Jurnal Manajemen/Volume XX, No.02.

58. Wirawan, (2007). Budaya dan Iklim Organisasi: Teori, Aplikasi, dan Penelitian. Jakarta: Salemba Empat. 